\title{
Optimized culture condition for enhancing lytic performance of waste activated sludge by Geobacillus sp. G1
}

\author{
Chunxue Yang, Aijuan Zhou, Yanan Hou, Xu Zhang, Zechong Guo, \\ Aijie Wang and Wenzong Liu
}

\begin{abstract}
Hydrolysis is known as the rate-limiting step during waste activated sludge (WAS) digestion. The optimization of the culture conditions of Geobacillus sp. G1 for enhancing WAS hydrolysis was conducted in this study with uniform design and response surface methodology. Taking the lysis rate of Escherichia coli as the response, the Plackett-Burman design was used to screen the most important variables. Experimental results showed that the maximum predicted lysis rate of $E$. coli was $50.9 \%$ for $4 \mathrm{~h}$ treatment time with concentrations of skim milk, $\mathrm{NaCl}$ and $\mathrm{NH}_{4} \mathrm{SO}_{4}$ at $10.78,4.36$ and $11.28 \mathrm{~g} / \mathrm{L}$, respectively. The optimized dosage ratio of Geobacillus sp. G1 to WAS was 35\%:65\% $\left(V_{\mathrm{G} 1}: V_{\mathrm{WAS}}\right)$. Under this condition, soluble protein was increased to $695 \mathrm{mg}$ chemical oxygen demand $(\mathrm{COD}) / \mathrm{L}$, which was 5.0 times higher than that obtained in the control (140 mg COD/L). The corresponding protease activity reached $1.1 \mathrm{Eu} / \mathrm{mL}$. Scanning electron microscopy showed that abundant cells were apparently lysed with treatment of Geobacillus sp. G1.

Key words | Geobacillus, lytic performance, response surface methodology (RSM), uniform design (UD), waste activated sludge (WAS)

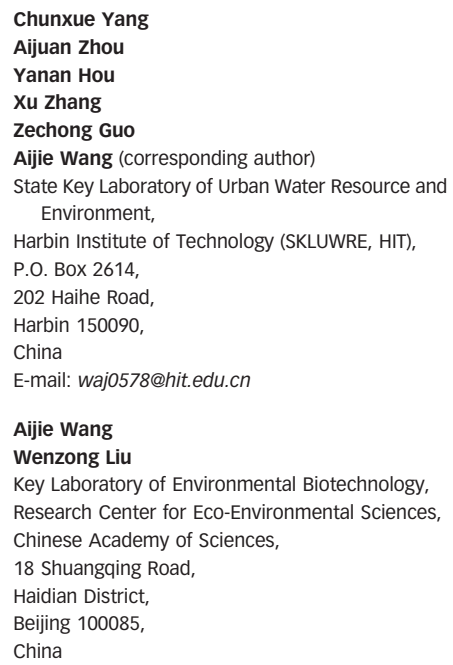

\section{INTRODUCTION}

As the main waste generated from wastewater treatment plants, waste activated sludge (WAS) poses many problems because of its requirement for special handling and disposal techniques (Khursheed \& Kazmi 20Ir; Nielsen et al. 20II). The predominant component of WAS is bacterial mass, especially for Gram-negative cells (Snaidr et al. 1997; Lu et al. 2012). Unlike Gram-positive bacteria, the outer membrane of Gram-negative bacteria is composed of protein and lipopolysaccharide, which protect the cell from direct chemical attack (Khursheed \& Kazmi 20II). Meanwhile, most of the biodegradable material in WAS is either enclosed in the microbial cell wall or enmeshed in the extracellular polymeric matrix (Neyens \& Baeyens 2003). Therefore, cell disruption is a prerequisite constituent for WAS treatment (Kim et al. 2002; Yi et al. 20I3). Since over $50 \%$ of organic materials in WAS are protein, considerable attention has been paid to the enzymatic hydrolysis of proteins for the improvement of sludge digestibility
(Kim et al. 2002; Wang et al. 2014). The utilization of extracellular hydrolytic enzymes or thermophilic bacteria can be taken as an efficient biological pretreatment for the solubilization of WAS (Guo et al. 2012; Huang et al. 20I4).

In recent years, many researchers have shown that the pretreatment of a thermophilic bacteria strain can enhance sludge reduction. Hasegawa et al. (2000) reported that organic sludge solubilization was $18 \%$ with $5 \mathrm{~h}$ treatment by supernatant while it was $40 \%$ for 1-2 days treatment by a suspension of Bacillus sp. SPT2-1, both at $65^{\circ} \mathrm{C}$. Li et al. (2009) obtained 54.8\% total suspended solids (TSS) removal with the aerobic digestion of sludge by sludge-lysing bacteria. Guo et al. (2010) used the S-TE method with a dosage of Bacillus sp. AT07-1 to pretreat WAS and obtained $933.6 \mathrm{mg} / \mathrm{L}$ soluble protein with $967 \mathrm{mg} / \mathrm{L}$ as the control, both pretreated at $65{ }^{\circ} \mathrm{C}$ for $24 \mathrm{~h}$. To sum up, treatment with supernatants of thermophilic bacteria has the advantage of easy maintenance and management. However, 
there is no report on the statistical optimization of process parameters on lytic performance.

Plackett-Burman design (PBD) and uniform designresponse surface methodology (UD-RSM) are an established mathematical optimization procedure and have been well applied to the analysis and optimization of models in some bioprocesses (Chen et al. 20II; Wang et al. 20II). Therefore, the objective of this study was to optimize culture conditions to enhance the lytic performance of WAS by Geobacillus sp. G1. This work combined PBD and UDRSM, scanning electron microscopy (SEM) and calculation of lysis rate to get the maximum lysis rate of the microbial cells.

\section{MATERIALS AND METHODS}

\section{Source of WAS}

WAS was collected from the secondary sedimentation tank of Taiping Municipal Wastewater Treatment Plant (Harbin City, Heilongjiang Province, China). The sludge was concentrated by settling for $24 \mathrm{~h}$ at $4{ }^{\circ} \mathrm{C}$, and screened with a $1 \mathrm{~mm}$ sieve to remove impurities, then stored at $4{ }^{\circ} \mathrm{C}$ prior to tests. Its characteristics are mainly as follows: $\mathrm{pH} 6.72 \pm 0.5$, TSS $25,960 \pm 398 \mathrm{mg} / \mathrm{L}$, volatile suspended solids (VSS) $18,740 \pm 543 \mathrm{mg} / \mathrm{L}$, total chemical oxygen demand (TCOD) $24,362 \pm 297 \mathrm{mg} / \mathrm{L}$, soluble chemical oxygen demand (SCOD) $652 \pm 94 \mathrm{mg} / \mathrm{L}$, soluble protein $53 \pm$ $17 \mathrm{mg}$ COD/L, soluble carbohydrate $91 \pm 2 \mathrm{mg}$ COD/L and volatile fatty acids (VFAs) $237 \pm 61 \mathrm{mg} \mathrm{COD} / \mathrm{L}$.

\section{Isolation and cultivation of Geobacillus sp. G1}

WAS was incubated at $60^{\circ} \mathrm{C}$ for $7 \mathrm{~d}$ under aerobic conditions. After being diluted 10-fold with distilled water, the sludge sample was cultured by streaking onto skim milk agar medium containing (/L): $10 \mathrm{~g}$ skim milk, $3.0 \mathrm{~g}$ yeast extract, $6.7 \mathrm{~g}\left(\mathrm{NH}_{4}\right)_{2} \mathrm{SO}_{4}, 0.5 \mathrm{~g} \mathrm{NaCl}, 1.2 \mathrm{~g} \mathrm{~K}_{2} \mathrm{HPO}_{4}, 0.7 \mathrm{~g}$ $\mathrm{KH}_{2} \mathrm{PO}_{4}, 0.5 \mathrm{~g} \mathrm{MgSO}_{4} \cdot 7 \mathrm{H}_{2} \mathrm{O}, 15 \mathrm{~g}$ agar, $\mathrm{pH}=7$. After it was incubated at $60{ }^{\circ} \mathrm{C}$ for $48 \mathrm{~h}$, the representative strains of all colony types that could be distinguished were isolated by sub-culturing on the same skim milk plates until eventually a single colony was formed. The isolated typical strain was preserved in the refrigerator at $4{ }^{\circ} \mathrm{C}$.

Geobacillus sp. G1 was incubated in skim milk liquid medium, shaken at $140 \mathrm{rpm}$ for $24 \mathrm{~h}$ at $60{ }^{\circ} \mathrm{C}$ to achieve the stationary-growth phase $\left(\mathrm{Abs}_{600}\right.$ of about 1.0). The culture supernatants were used for the lysis of Escherichia coli and WAS by centrifuging at $10,000 \mathrm{rpm}$ for $10 \mathrm{~min}$ at $4{ }^{\circ} \mathrm{C}$, and filtrating with sterilized $0.22 \mu \mathrm{m}$ membrane filters.

\section{Experimental design and optimization}

\section{Plackett-Burman design}

PBD was used to determine factors that significantly influenced the lytic performance of long-cultured $E$. coli, which was based on the linear equation model (Rajendran \& Thangavelu 2009; Wee et al. 2009)

$Y=A_{0}+\Sigma A_{i} X_{i}$

where $Y$ represents the lysis rate, $A_{0}$ represents the model intercept, $A_{i}$ represents the linear coefficient and $X_{i}$ represents the level of the independent variable.

Eight parameters, skim milk, yeast extract, $\left(\mathrm{NH}_{4}\right)_{2} \mathrm{SO}_{4}$, $\mathrm{NaCl}, \mathrm{K}_{2} \mathrm{HPO}_{4}, \mathrm{KH}_{2} \mathrm{PO}_{4}, \mathrm{MgSO}_{4} \cdot 7 \mathrm{H}_{2} \mathrm{O}$ and $\mathrm{pH}$, were selected as the examining factors to investigate the culture conditions significant for influencing the lysis rate of $E$. coli. All experiments were carried out in triplicate. Based on the PBD, each variable was examined at two levels: -1 for low level and +1 for high level. In this study, eight assigned variables were screened in 12 experimental designs. Supplementary Tables S1 and S2 (available online at http://www.iwaponline.com/wst/070/149.pdf) illustrate the levels of each factor and the design matrix used in the experimental design, respectively.

\section{UD-RSM design for optimization of culture conditions}

Based on the PBD result, the optimal experiment was further expanded to a UD design. The significant factors identified from PBD, skim milk $\left(X_{1}, \mathrm{~g} / \mathrm{L}\right),\left(\mathrm{NH}_{4}\right)_{2} \mathrm{SO}_{4}\left(X_{3}\right.$, $\mathrm{g} / \mathrm{L}), \mathrm{NaCl}\left(X_{6}, \mathrm{~g} / \mathrm{L}\right)$, were arranged as independent variables, each at six levels (Table 1 ). The UD table $\mathrm{U}_{12}\left(12^{3}\right)$ was applied to arrange the experiments (Table 2). Lysis rate $(Y, \%)$ of $E$. coli cells was taken as the response variable, a second-order polynomial function was used to connect the

Table 1 | Levels of the variable tested in the $U_{12}\left(12^{3}\right)$ uniform designs

\begin{tabular}{lrrrrrr} 
& \multicolumn{7}{c}{ Range and levels } \\
\cline { 2 - 7 } Variables & \multicolumn{1}{c}{$\mathbf{1}$} & \multicolumn{1}{c}{$\mathbf{2}$} & \multicolumn{1}{c}{$\mathbf{3}$} & \multicolumn{1}{c}{$\mathbf{4}$} & \multicolumn{1}{c}{$\mathbf{5}$} & $\mathbf{6}$ \\
\hline$X_{1}$, skim milk (g/L) & 10 & 11 & 12 & 13 & 14 & 15 \\
$X_{3}, \mathrm{NH}_{4} \mathrm{SO}_{4}(\mathrm{~g} / \mathrm{L})$ & 7 & 8 & 9 & 10 & 11 & 12 \\
$X_{6}, \mathrm{NaCl}(\mathrm{g} / \mathrm{L})$ & \multicolumn{1}{c}{0} & 1 & 2 & 3 & 4 & 5 \\
\hline
\end{tabular}


Table 2 | UD and response results for the study of three experimental variables in coded units

\begin{tabular}{|c|c|c|c|c|c|c|c|c|c|c|}
\hline \multirow[b]{2}{*}{ Run } & \multirow[b]{2}{*}{$x_{1}$} & \multirow[b]{2}{*}{$x_{3}$} & \multirow[b]{2}{*}{$x_{6}$} & \multicolumn{3}{|c|}{ Factors } & \multirow[b]{2}{*}{ Skim milk (g/L) } & \multirow[b]{2}{*}{$\mathrm{NH}_{4} \mathrm{SO}_{4}(\mathrm{~g} / \mathrm{L})$} & \multicolumn{2}{|l|}{ Response } \\
\hline & & & & $x_{1}$ & $x_{3}$ & $x_{6}$ & & & $\mathrm{NaCl}(\mathrm{g} / \mathrm{L})$ & Lysis rate (\%) \\
\hline 1 & 1 & 6 & 10 & 1 & 3 & 5 & 10 & 9 & 4 & 35.06 \\
\hline 2 & 2 & 12 & 7 & 1 & 6 & 4 & 10 & 12 & 3 & 44.98 \\
\hline 3 & 3 & 5 & 4 & 2 & 3 & 2 & 11 & 9 & 2 & 34.08 \\
\hline 4 & 4 & 11 & 1 & 2 & 6 & 1 & 11 & 12 & 0 & 25.37 \\
\hline 5 & 5 & 4 & 11 & 3 & 2 & 6 & 12 & 8 & 5 & 45.24 \\
\hline 6 & 6 & 10 & 8 & 3 & 5 & 4 & 12 & 11 & 3 & 50.35 \\
\hline 7 & 7 & 3 & 5 & 4 & 2 & 3 & 13 & 8 & 1 & 51.51 \\
\hline 8 & 8 & 9 & 2 & 4 & 5 & 1 & 13 & 11 & 0 & 25.44 \\
\hline 9 & 9 & 2 & 12 & 5 & 1 & 6 & 14 & 7 & 5 & 44.36 \\
\hline 10 & 10 & 8 & 9 & 5 & 4 & 5 & 14 & 10 & 4 & 50.19 \\
\hline 11 & 11 & 1 & 6 & 6 & 1 & 3 & 15 & 7 & 2 & 29.79 \\
\hline 12 & 12 & 7 & 3 & 6 & 4 & 2 & 15 & 10 & 1 & 26.78 \\
\hline
\end{tabular}

independent variables and the response (Ebrahimpour et al. 2008; Zhou et al. 20I2).

The Design Expert (Version 7.1.0, Stat-Ease Inc., Minneapolis, MN, USA) software was used for regression and graphical analyses of the data obtained. The interactive effects of the independent variables on the dependent ones were illustrated by three- and two-dimensional contour plots. All experimental designs were randomized, and mean values were applied.

\section{WAS fermentation test under optimized conditions}

Lytic performance of WAS microbial cells cited SCOD solubilization as an indicator for microbial cell fractionation, through adding different volumes of culture supernatant of Geobacillus sp. G1 to WAS. The WAS microbial cells were concentrated by centrifuging at 5,000 rpm for $10 \mathrm{~min}$, washed twice with fresh buffer $(0.05 \mathrm{~mol} / \mathrm{L}$ Tris- $\mathrm{HCl} \mathrm{pH}$ 8.5), and suspended at $20{ }^{\circ} \mathrm{C}$. The dosage rates of $\mathrm{G} 1$ supernatants to WAS were 25\%:75\%, 35\%:65\%, 50\%:50\% and 65\%:35\% ( $\left.V_{\mathrm{G} 1}: V_{\mathrm{WAS}}\right)$, respectively. The blank was treated with sterilized supernatant of G1 simultaneously. Finally, 300 millilitres of mixture were placed in $500 \mathrm{~mL}$ Erlenmeyer flasks, cultivated for $4 \mathrm{~h}$ in a water bath at $60{ }^{\circ} \mathrm{C}$.

\section{Analytical methods}

Total DNA from the isolated strain was extracted with a fast DNA Spin kit (Sunrise) according to the manufacturer's instructions. 16S rDNA was amplified by polymerase chain reaction (PCR) amplification using universal primers 27F and 1525R (Nakatsu 2007). PCR products were purified and sequenced by Beijing Genomics Institute, China. The nucleotide sequences were compared with sequences in the NCBI (http://blast.ncbi.nlm.nih.gov/Blast.cgi) and the EZTaxon nucleotide sequence databases (http://eztaxon-e. ezbiocloud.net/) using the BLAST search, and the sequence alignment and evolutionary distance tree analysis used MEGA 4.1.

A loopful of $E$. coli (TAKARA) was incubated in LB liquid, shaken at $140 \mathrm{rpm}$ for $72 \mathrm{~h}$ at $37^{\circ} \mathrm{C}$. The culture of $E$. coli was harvested by centrifugation at $5,000 \mathrm{rpm}$ for $10 \mathrm{~min}$ at room temperature, washed twice in fresh buffer $(0.05 \mathrm{~mol} / \mathrm{L}$ Tris$\mathrm{HCl}$ [pH 8.5]), and suspended in the same buffer to give an $\mathrm{Abs}_{540}$ of about 1.4. This cell suspension was mixed with the same volume of the culture supernatant of Geobacillus sp. $\mathrm{G} 1$ in a cuvette in a $60^{\circ} \mathrm{C}$ water bath, The lysis rate of microbial cells was measured by the decrease in absorbance of cell supernatant (Dean \& Ward I99I; Song \& Hu 2006).

The sludge samples were centrifuged at 10,000 rpm for $10 \mathrm{~min}$, filtered through a $0.45 \mu \mathrm{m}$ cellulose nitrate membrane filter for subsequent analysis. The determinations of VFAs, SCOD, TCOD, TSS, VSS, carbohydrate and protein were performed as previously described (Zhou et al. 20I3a, $2013 \mathrm{~b})$. The calculation of the lysis rate of the sludge was conducted according to previous studies (Foladori et al. 20Io). The measurement of protease activity was conducted with Kim's methods (Kim et al. 2002); one unit of enzyme activity was defined as the amount of enzyme which degraded $1 \mathrm{mg}$ azocasein at $60{ }^{\circ} \mathrm{C}$. 
The contribution values of per mL supernatants of Geobacillus sp. G1 to the additional soluble protein concentrations were calculated as follows:

Contribution value $=\left(\operatorname{Protein}_{x}-\right.$ Protein $\left._{0}\right) / V_{G 1}$

where $\operatorname{Protein}_{\mathrm{x}}$ represents the soluble protein concentrations obtained by adding the supernatant of Geobacillus

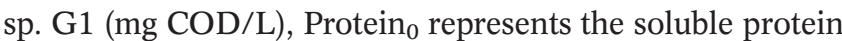
concentrations obtained in the blank test (mg COD/L), $V_{\mathrm{G} 1}$ represents the volume of the added supernatants of $\mathrm{G} 1$.

The bacterial and WAS samples were sputter coated with $10 \mathrm{~nm} \mathrm{Au}$ and examined by SEM (Helios Nanolab $600 \mathrm{i}$; FEI, Ltd) at an accelerating voltage of $20 \mathrm{kV}$. The bacterial samples were diluted and examined by atomic force microscope (AFM) (Dimension Icon; BRUKER, GMBH).

\section{RESULTS AND DISCUSSION}

\section{Isolation and identification of Geobacillus sp. G1}

The thermophilic bacteria isolated from WAS at $60{ }^{\circ} \mathrm{C}$ formed a halo of colourless agar on the plates, and was christened G1. The SEM and AFM micrographs are shown in Supplementary Figure S1 (available online at http://www. iwaponline.com/wst/070/149.pdf). Physiological and biochemical analysis showed that the strain was rod-shaped, Gram-positive and facultative anaerobic. Phylogenetic analysis based on 16S rRNA gene sequences revealed that strain G1 was a member of the family Geobacillus and so was named Geobacillus sp. G1 (accession no. JX522538). Within each of the Geobacillus species groups, the strains had almost identical 16S rRNA sequences (>96\%) and exhibited high DNA homology (Kuisiene et al. 2007). The sequence of strain G1 was most similar to those of G. kaustophilus, G. thermoleovorans, G. vulcani and G. lituanicus (99.1499.79\% sequence similarity). Evolutionary distance tree analysis shows that strain G1 was closest to G. lituanicus (AY044055) (Supplementary Figure S2, available online at http://www.iwaponline.com/wst/070/149.pdf).

\section{Optimization of the lytic performance for Geobacillus sp. G1}

PBD was used as a screening method to determine which factors of skim milk, yeast extract, $\left(\mathrm{NH}_{4}\right)_{2} \mathrm{SO}_{4}, \mathrm{NaCl}, \mathrm{K}_{2} \mathrm{HPO}_{4}$, $\mathrm{KH}_{2} \mathrm{PO}_{4}, \mathrm{MgSO}_{4} \cdot 7 \mathrm{H}_{2} \mathrm{O}$ and $\mathrm{pH}$ significantly affect lytic performance. The experimental design and corresponding lysis rate are shown in Supplementary Table S1. The effect of each variable on lysis rate was determined by the difference between the average of measurements made at the high level and the low level of the factor. From the regression analysis in Table S2, it was found that skim milk, $\left(\mathrm{NH}_{4}\right)_{2} \mathrm{SO}_{4}, \mathrm{KH}_{2} \mathrm{PO}_{4}$ and $\mathrm{NaCl}$ displayed a positive effect for lytic performance of $E$. coli, whereas yeast extract, pH, $\mathrm{K}_{2} \mathrm{HPO}_{4}$ and $\mathrm{MgSO}_{4}$. $7 \mathrm{H}_{2} \mathrm{O}$ had a negative effect on lytic performance of $E$. coli. Skim milk, $\left(\mathrm{NH}_{4}\right)_{2} \mathrm{SO}_{4}$ and $\mathrm{NaCl}$ had higher contributions than the other variables and hence were considered to be significant. $\mathrm{KH}_{2} \mathrm{PO}_{4}$, yeast extract, $\mathrm{pH}, \mathrm{K}_{2} \mathrm{HPO}_{4}$ and $\mathrm{MgSO}_{4}$. $7 \mathrm{H}_{2} \mathrm{O}$ were considered insignificant, and were not included in the next optimization experiments.

Based on the results of the initial PBD, skim milk $\left(X_{1}\right)$, $\left(\mathrm{NH}_{4}\right)_{2} \mathrm{SO}_{4}\left(X_{3}\right)$ and $\mathrm{NaCl}\left(X_{6}\right)$ were quantitatively evaluated on a model corresponding to UD. The levels of the variable were tested in the $U_{12}\left(12^{3}\right)$ design (Table 1). The experimental design and results investigated are shown in Table 2. By applying multiple regression analysis on the experimental data, a second-order polynomial equation was obtained to describe the correlation between the significant variables and lysis rate of $E$. coli cells in terms of decoded values:

$$
\begin{aligned}
Y= & -649.59+63.58 X_{1}+50.71 X_{3}+21.48 X_{6} \\
& -1.70 X_{1} X_{3}-0.15 X_{1} X_{6}-0.59 X_{3} X_{6}-1.82 X_{1}^{2} \\
& -1.30 X_{3}^{2}-1.54 X_{6}^{2}
\end{aligned}
$$

where $Y$ is the predicted lysis rate, and $X_{1}, X_{3}$ and $X_{6}$ are the coded values of skim milk, $\left(\mathrm{NH}_{4}\right)_{2} \mathrm{SO}_{4}$ and $\mathrm{NaCl}$ concentrations, respectively.

$F$-value and $P$-value for each variable in the polynomial model are presented in Supplementary Table S3 (available online at http://www.iwaponline.com/wst/070/149.pdf). The analysis of variance was conducted to test the significance of the fit of the second-order polynomial equation for the lysis rate. The $F$-value of 190.54 implies the model is significant, because values of 'Prob $>F$ ' less than 0.0500 are considered to be significant. There was only a $0.52 \%$ chance it could occur due to noise which presented as adequate precision (46.330). In addition, the models did not show lack-of-fit and presented a high determination coefficient $\left(R^{2}=0.9988\right)$, explaining $99.88 \%$ of variability in the responses, and $X_{3}, X_{1} X_{6}, X_{3} X_{6}$, $X_{1}^{2}, X_{3}^{2}, X_{6}^{2}$ were significant model terms. Therefore, Equation (3) properly describes the lytic performance in this study.

From Equation (3), the optimal values of $X_{1}, X_{3}$ and $X_{6}$ in the model were $10.78,11.28$ and $4.36 \mathrm{~g} / \mathrm{L}$ respectively, and the maximum predicted value of lysis rate was $50.9 \%$. 

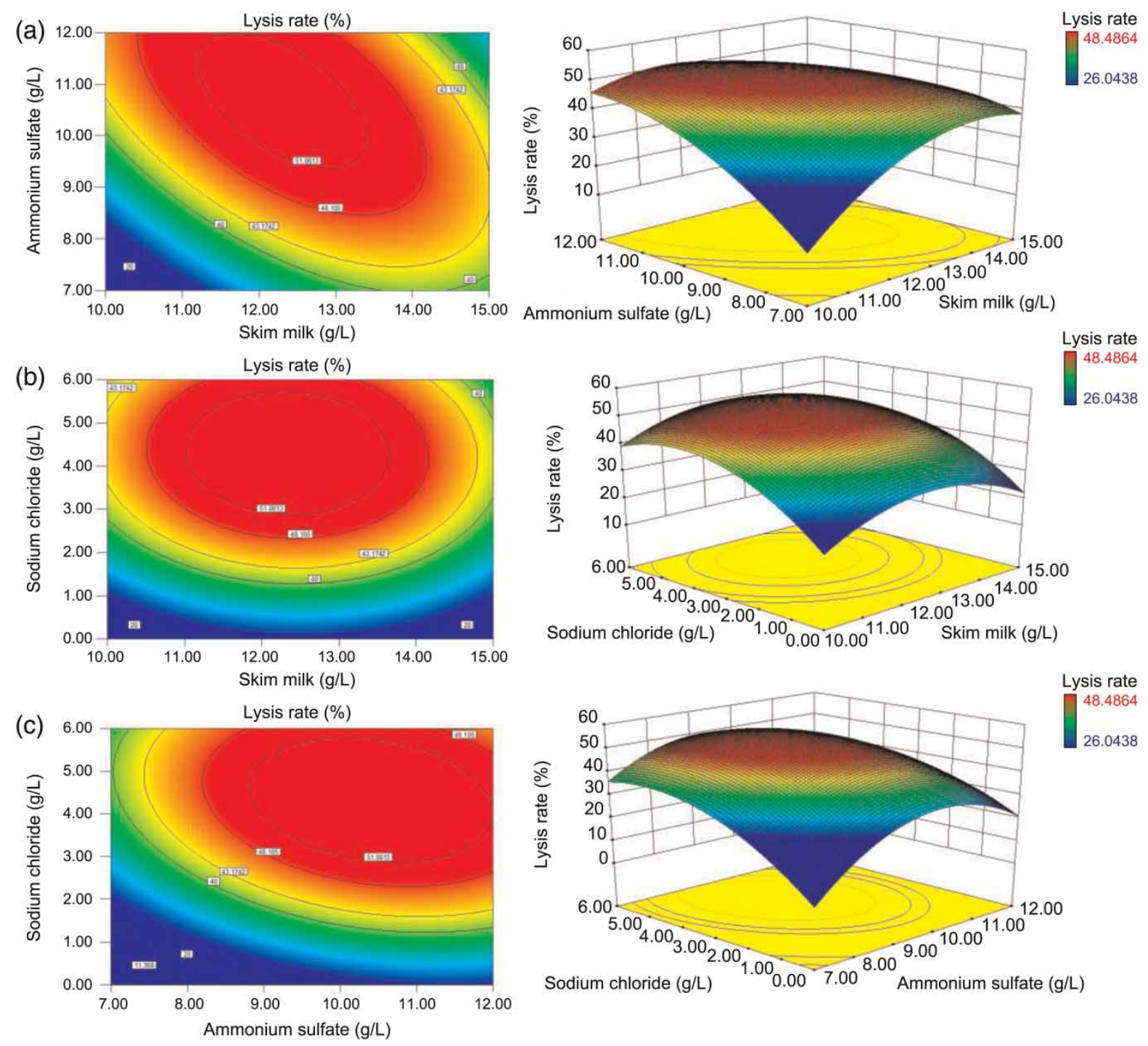

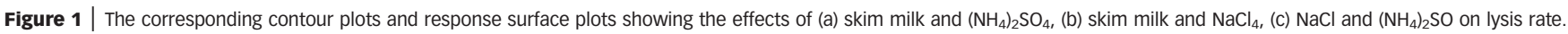

The corresponding contour plots and response surface plots are shown in Figure 1 based on Equation (3) with one variable being kept constant at its optimum level, and varying the other two variables with the experimental range. As can be seen from Figure 1, the response surface of the lysis rate showed a clear peak, indicating that the optimum conditions were well inside the design boundary. Lysis rate increased with increasing skim milk, $\left(\mathrm{NH}_{4}\right)_{2}$ $\mathrm{SO}_{4}$ and $\mathrm{NaCl}$ to optimum conditions and then decreased with further increase. This result indicates that skim milk, $\left(\mathrm{NH}_{4}\right)_{2} \mathrm{SO}_{4}$ and $\mathrm{NaCl}$ each had an individual significant influence on lysis rate. In addition, the concentration of the three factors reflected both positive and negative effects due to the appropriate increasing of their concentration which could efficiently improve the lysis. By contrast, superfluous nutrient may inhibit the production of extracellular enzymes that result in a low lysis rate.

\section{Validation of the model}

In order to confirm the validity of the statistical experimental strategy and to acquire a better understanding of lytic performance by Geobacillus sp. G1, repeated experiments under optimal conditions were carried out. According to the results of UD-RSM, the optimized and economical medium was prepared as follows (/L): $10.78 \mathrm{~g}$ skim milk, $3.0 \mathrm{~g}$ yeast extract, $11.28 \mathrm{~g}\left(\mathrm{NH}_{4}\right)_{2} \mathrm{SO}_{4}, 4.3 \mathrm{~g} \mathrm{NaCl}, 1.2 \mathrm{~g}$ $\mathrm{K}_{2} \mathrm{HPO}_{4}, 0.7 \mathrm{~g} \mathrm{KH}_{2} \mathrm{PO}_{4}, 0.5 \mathrm{~g} \mathrm{MgSO}_{4} \cdot 7 \mathrm{H}_{2} \mathrm{O}, 15 \mathrm{~g}$ agar, $\mathrm{pH}=7$. 
Table 3 | Comparison of lysis rate of E. coli or WAS under optimized conditions

\begin{tabular}{|c|c|c|c|c|c|c|}
\hline Microorganism & Substrate & Temperature ( $\mathrm{C}$ ) & Time (h) & pH & Lysis rate (\%) & Reference \\
\hline Geobacillus sp. SY9 & E. coli & 60 & 4 & 7 & 15 & Song et al. (20IO) \\
\hline Geobacillus sp. SY14 & E. coli & 60 & 4 & 7 & 20 & Song et al. (20IO) \\
\hline Geobacillus sp. SY9 + Geobacillus sp. SY14 & E. coli & 60 & 4 & 7 & 42 & Song et al. (20IO) \\
\hline Geobacillus sp. G1 & E. coli & 60 & 4 & 7 & 50.10 & This study \\
\hline Exiguobacterium sp. YS1 & WAS & 28 & 120 & 9 & 15 & Sun et al. (2009) \\
\hline Bacillus sp. SPT2-1 & WAS & 65 & 5 & / & 18 & Guo et al. (2010) \\
\hline Geobacillus sp. G1 & WAS & 60 & 4 & / & 36.60 & This study \\
\hline
\end{tabular}

In the above mentioned optimized conditions, the lysis rate of $E$. coli cells was $50.1 \% \pm 0.3 \%$ by supernatants of Geobacillus sp. G1 at $60^{\circ} \mathrm{C}$. The excellent correlation between predicted and measured values verifies the model's validation and the existence of an optimal point. A comparison of lytic performance by thermophilic bacteria including Geobacillus sp. G1 with and without optimum medium components is given in Table 3 . The lysis rate obtained for Geobacillus sp. G1 was higher than those reported in other studies. Hasegawa et al. (2000) reported that the organic sludge solubilization was $18 \%$ with $5 \mathrm{~h}$ treatment by the supernatants, while it was $40 \%$ for $1-2$ days treatment by a suspension of Bacillus sp. SPT2-1 both at $65^{\circ} \mathrm{C}$ (Table 3). Compared with this, inoculating with the stable extracellular enzyme activity of culture supernatants could shorten the pretreatment time. Removing the thermophilic bacteria could decrease the consumption of the soluble organic materials and increase their utilization. Moreover, the maximum lysis rate could be $50.1 \%$ after medium optimization, which was $10.6 \%$ higher than the results without optimization. The activity of protease was $3.4 \mathrm{Eu} / \mathrm{mL}$ after optimization, and only $1.7 \mathrm{Eu} / \mathrm{mL}$ without optimization.

In the whole lytic process, the lysis rate of inoculated groups was higher than the blank for $4 \mathrm{~h}$ treatment time (Figure 2). Obvious solubilization levels were obtained with the different dosage ratios of Geobacillus sp. G1 culture supernatants $\left(V_{\mathrm{G} 1}: V_{\mathrm{WAS}}\right)$ at $60^{\circ} \mathrm{C}$. The lysis rate and the release of soluble protein were raised with the increased dosage of G1 supernatants. The maximum lysis rate was $36.6 \%$ with the G1 dosage rate of $65 \%: 35 \%$, which was 12.6-fold higher than the blank with the rate of 2.9\% (Figure 2(a)). This finding showed that different dosage ratios of Geobacillus sp. G1 culture supernatants $\left(V_{\mathrm{G} 1}: V_{\mathrm{WAS}}\right)$ had great influence on WAS solubilization, and the supernatants of Geobacillus sp. G1 accelerated
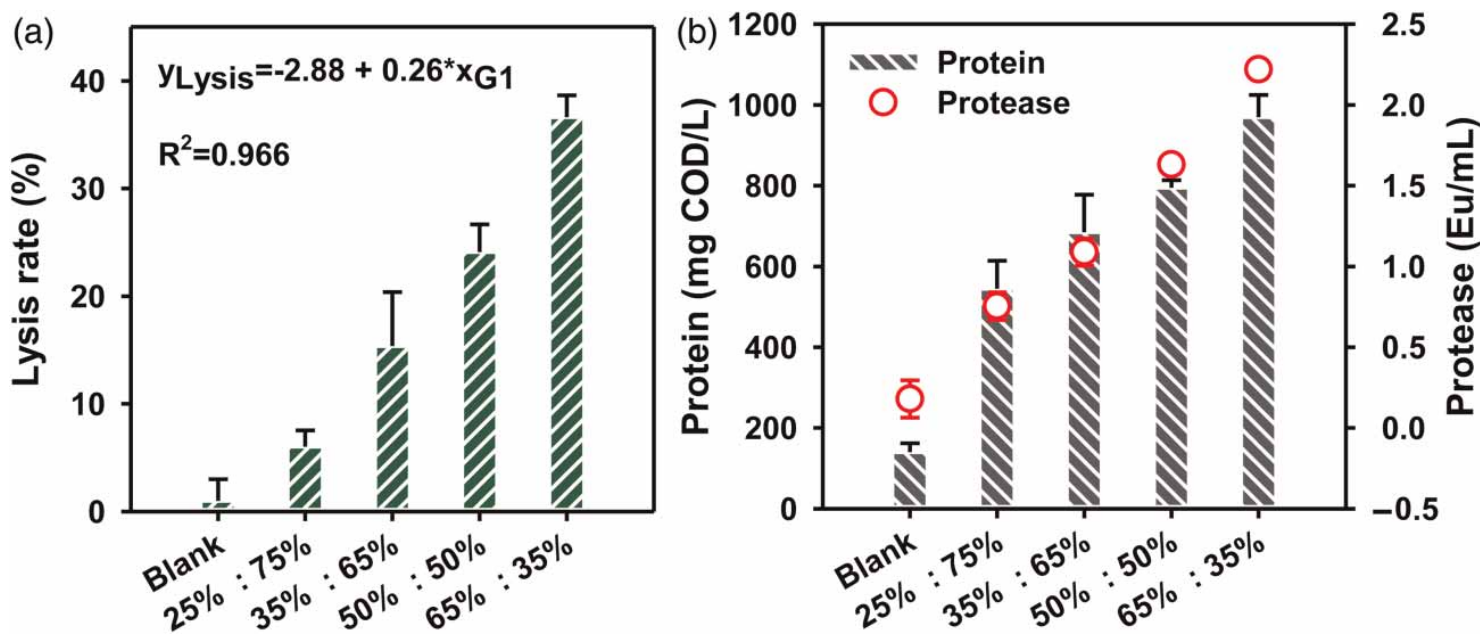

Figure 2 (a) The lysis rate of WAS microbial cells; (b) the concentration of soluble protein and relative protease activity at different volumes of Geobacillus sp. G1 culture supernatants $\left(V_{\mathrm{G} 1}: V_{\text {WAS }}\right)$ at $60{ }^{\circ} \mathrm{C}$. 

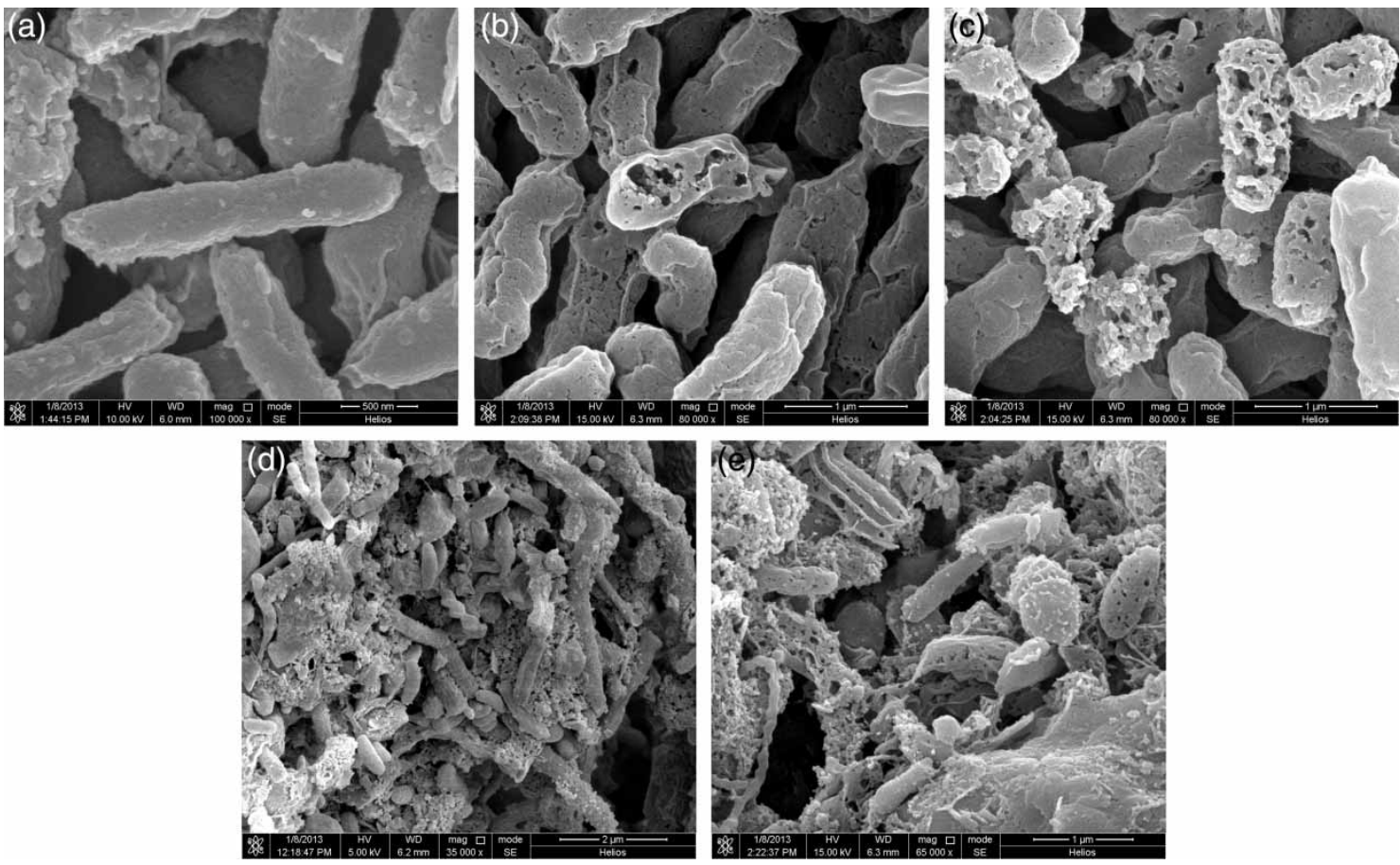

Figure 3 SEM micrographs of $E$. coli and WAS before and after lytic treatment with the culture supernatants of Geobacillus sp. G1 for $4 \mathrm{~h}$ treatment time at $60{ }^{\circ} \mathrm{C}$. (a) Blank: $E$. coli without treatment; (b) E. coli with lytic treatment by $\mathrm{G} 1$ before optimization $\left(V_{\mathrm{G} 1}: V_{E .}\right.$ coli $\left.=50 \%: 50 \%\right)$; (c) $E$. coli with lytic treatment by $\mathrm{G} 1$ after optimization $\left(V_{\mathrm{G} 1}: V_{E \text {. coli }}=50 \%: 50 \%\right) ;(\mathrm{d})$ Blank: WAS without treatment; (e) WAS with lytic treatment by G1 after optimization $\left(V_{\mathrm{G} 1}: V_{\mathrm{WAS}}=65 \%: 35 \%\right)$.

WAS hydrolysis by producing thermostable enzymes. The highest contribution value of per mL G1 supernatants for $4 \mathrm{~h}$ to the additional soluble protein appeared in the $35 \%$ G1 dosage test (1.7 mg protein (as COD)/mL G1/L), which was 1.4-fold, 1.3-fold and 1.1-fold of that in the $65 \%, 50 \%$, and $25 \%$ G1 dosage tests, respectively. Thereby, the appropriate dosage rate of G1 was 35\%. The concentration of soluble protein was $695 \mathrm{mg}$ COD/L with $35 \%$ G1 dosage, while it was only $140 \mathrm{mg} \mathrm{COD} / \mathrm{L}$ in the blank, and thus 5.0-fold higher than that obtained in the blank (Figure 2(b)). Previous studies also showed almost the same approach to enhancing WAS hydrolysis using thermophilic bacteria. Li et al. (2009) concluded that the concentration of soluble protein was about $270 \mathrm{mg} / \mathrm{L}$ obtained in the inoculated Brevibacillus sp. KH3 $(1 \mathrm{~mL} / 100 \mathrm{~g}$ WAS) at $55^{\circ} \mathrm{C}$ for $4 \mathrm{~h}$.

SEM observation showed that abundant E. coli cells were apparently lysed with treatment of Geobacillus sp. G1 (Figure 3). The lytic performance of E. coli cells presented broken parts of cell surface at $4 \mathrm{~h}$ treatment, while most parts of cells were lysed substantially after optimized treatment by the supernatants of Geobacillus sp. G1. The same phenomenon appeared in the lytic performance of WAS. The addition of culture supernatants presented a rapid and effective method for enhancing lytic performance. Thus, the extracellular enzymes of Geobacillus sp. G1 could lyse WAS effectively, and the appropriate volume of optimized culture supernatants could promote WAS microbial cell lysis, and maintain the relative activity of extracellular enzymes simultaneously.

\section{CONCLUSIONS}

In this study, the activity of extracellular enzymes of Geobacillus sp. G1 was improved by optimizing the culture medium, based on the UD-RSM. Under optimal conditions, the maximum lysis rate of E. coli was $50.1 \%$ compared to the predicted rate of $50.9 \%$. Subsequent batch experiments revealed the highest lysis rate of WAS microbial cells was up to $36.6 \%$ with the G1 dosage of $65 \%$. Considering the enzyme contribution of the supernatants of Geobacillus sp. G1, the appropriate dosage ratio was 35\%:65\%. Under this condition, soluble protein was increased to $695 \mathrm{mg}$ $\mathrm{COD} / \mathrm{L}$, and the corresponding protease activity reached $1.1 \mathrm{Eu} / \mathrm{mL}$. This result suggested that UD-RSM offered an efficient and feasible approach for enhancing the lytic performance of WAS by Geobacillus sp. G1. 


\section{ACKNOWLEDGEMENTS}

This research was supported by the National Science Foundation for Distinguished Young Scholars (grant no. 51225802), Science Fund for Creative Research Groups (grant no. 51121065), National Natural Science Foundation of China (grant no. 51208496), National High-tech R\&D Program of China (863 Program, grant no. 2012AA051502), National Key Technology Research and Development Program of the Ministry of Science and Technology of China (2010BAC67B02), 'Hundred Talents Program' of the Chinese Academy of Sciences, and Heilongjiang Science Foundation for Distinguished Young Scholars (grant no. JC201003).

\section{REFERENCES}

Chen, X. H., Lou, W. Y., Zong, M. H. \& Smith, T. J. 20II Optimization of culture conditions to produce high yields of active Acetobacter sp. CCTCC M209061 cells for anti-Prelog reduction of prochiral ketones. BMC Biotechnol. 11 (1), 110.

Dean, C. R. \& Ward, O. P. I99I Nature of Escherichia coli cell lysis by culture supernatants of Bacillus species. Appl. Environ. Microbiol. 57 (7), 1893-1898.

Ebrahimpour, A., Rahman, N., Ean Ch'ng, D., Basri, M. \& Salleh, A. 2008 A modeling study by response surface methodology and artificial neural network on culture parameters optimization for thermostable lipase production from a newly isolated thermophilic Geobacillus sp. strain ARM. BMC Biotechnol. 8 (1), 1-15.

Foladori, P., Tamburini, S. \& Bruni, L. 20Io Bacteria permeabilisation and disruption caused by sludge reduction technologies evaluated by flow cytometry. Water Res. 44 (17), 4888-4899.

Guo, L., Li, X. M., Zeng, G. M., Zhu, X., Yang, Q. \& She, Z. 2010 Enhanced hydrogen production from sewage sludge pretreated by thermophilic bacteria. Energ. Fuel. 24, 6081-6085.

Guo, L., Zhao, J., She, Z., Lu, M. \& Zong, Y. 2012 Effect of S-TE (solubilization by thermophilic enzyme) digestion conditions on hydrogen production from waste sludge. Bioresour. Technol. 117, 368-372.

Hasegawa, S., Shiota, N., Katsura, K. \& Akashi, A. 2000 Solubilization of organic sludge by thermophilic aerobic bacteria as a pretreatment for anaerobic digestion. Water Sci. Technol. 41 (3), 163-169.

Huang, L., Chen, B., Pistolozzi, M., Wu, Z. \& Wang, J. 2014 Inoculation and alkali coeffect in volatile fatty acids production and microbial community shift in the anaerobic fermentation of waste activated sludge. Bioresour. Technol. 153, 87-94.
Khursheed, A. \& Kazmi, A. A. 2oIr Retrospective of ecological approaches to excess sludge reduction. Water Res. $\mathbf{4 8 ,}$ 4287-4310.

Kim, Y.-K., Bae, J.-H., Oh, B.-K., Lee, W. H. \& Choi, J.-W. 2002 Enhancement of proteolytic enzyme activity excreted from Bacillus stearothermophilus for a thermophilic aerobic digestion process. Bioresour. Technol. 82, 157-164.

Kuisiene, N., Raugalas, J., Stuknyte, M. \& Chitavichius, D. 2007 Identification of the genus Geobacillus using genus-specific primers, based on the16S-23SrRNA gene internal transcribed spacer. FEMS Microbiol. Lett. 277 (2), 165-172.

Li, X., Ma, H., Wang, Q., Matsumoto, S., Maeda, T. \& Ogawa, H. I. 2009 Isolation, identification of sludge-lysing strain and its utilization in thermophilic aerobic digestion for waste activated sludge. Bioresour. Technol. 100 (9), 2475-2481.

Lu, L., Xing, D. \& Ren, N. 2012 Pyrosequencing reveals highly diverse microbial communities in microbial electrolysis cells involved in enhanced $\mathrm{H}_{2}$ production from waste activated sludge. Water Res. 46 (7), 2425-2434.

Nakatsu, C. H. 2007 Soil microbial community analysis using denaturing gradient gel electrophoresis. Soil Sci. Soc. Am. J. 71 (2), 562-571.

Neyens, E. \& Baeyens, J. 2003 A review of thermal sludge pre-treatment processes to improve dewaterability. J. Hazard. Mater. 98 (1-3), 51-67.

Nielsen, H. B., Thygesen, A., Thomsen, A. B. \& Schmidt, J. E. 20 II Anaerobic digestion of waste activated sludge: comparison of thermal pretreatments with thermal inter-stage treatments. J. Chem. Technol. Biot. 86 (2), 238-245.

Rajendran, A. \& Thangavelu, V. 2009 Statistical experimental design for evaluation of medium components for lipase production by Rhizopus arrhizus MTCC 2233. LWT - Food Sci. Technol. 42 (5), 985-992.

Snaidr, J., Amann, R., Huber, I., Ludwig, W. \& Schleifer, K. H. I997 Phylogenetic analysis and in situ identification of bacteria in activated sludge. Appl. Environ. Microbiol. 63 (7), 2884-2896.

Song, Y. D. \& Hu, H. Y. 2006 Isolation and characterization of thermophilic bacteria capable of lysing microbial cells in activated sludge. Water Sci. Technol. 54 (9), 35-43.

Song, Y.-D., Hu, H.-Y. \& Zhou, Y.-X. 2oro Lysis of stationary-phase bacterial cells by synergistic action of lytic peptidase and glycosidase from thermophiles. Biochem. Eng. J. 52 (1), 44-49.

Sun, H. L., Chung, W. C., Young, J. Y. \& R. Y. H. 2009 Effect of alkaline protease-producing Exiguobacterium sp. YS1 inoculation on the solubilization and bacterial community of waste activated sludge. Bioresour. Technol. 100, 4597-4603.

Wang, J.-P., Chen, Y.-Z., Wang, Y., Yuan, S.-J. \& Yu, H.-Q. $20 I I$ Optimization of the coagulation-flocculation process for pulp mill wastewater treatment using a combination of uniform design and response surface methodology. Water Res. 45 (17), 5633-5640.

Wang, T., Shao, L., Li, T., Lü, F. \& He, P. 2014 Digestion and dewatering characteristics of waste activated sludge treated by an anaerobic biofilm system. Bioresour. Technol. 153, 131-136. 
Wee, Y.-J., Reddy, L. V. A., Chung, K.-C. \& Ryu, H.-W. 2009 Optimization of chitosanase production from Bacillus sp. RKY3 using statistical experimental designs. J. Chem. Technol. Biot. 84 (9), 1356-1363.

Yi, W. G., Lo, K. V. \& Mavinic, D. S. 2013 Effects of microwave, ultrasonic and enzymatic treatment on chemical and physical properties of waste-activated sludge. J. Environ. Sci. Heal. A 49 (2), 203-209.

Zhou, A., Peng, J., Chen, Z., Du, J., Guo, Z., Ren, N. \& Wang, A. 2012 Statistical optimization of operational parameters for enhanced naphthalene degradation by $\mathrm{TiO}_{2} / \mathrm{Fe}_{3} \mathrm{O}_{4}-\mathrm{SiO}_{2}$ photocatalyst. Int. J. Photoenergy 2012, 1-9.

Zhou, A., Guo, Z., Yang, C., Kong, F., Liu, W. \& Wang, A. 2orza Volatile fatty acids productivity by anaerobic co-digesting waste activated sludge and corn straw: effect of feedstock proportion. J Biotechnol. 168 (2), 234-239.

Zhou, A., Yang, C., Guo, Z., Hou, Y., Liu, W. \& Wang, A. 2013b Volatile fatty acids accumulation and rhamnolipid generation in situ from waste activated sludge fermentation stimulated by external rhamnolipid addition. Biochem. Eng. J. 77, 240-245.

First received 8 December 2013; accepted in revised form 5 March 2014. Available online 20 March 2014 